quirements, was supplied by 58 generating stations. Of these stations, 27 small ones supplied only four per cent of the total load, the average generating cost per unit being more than $\mathbf{1} \cdot \mathbf{5} d$. Five groups of large stations supplied 66 per cent of the total load, the average generating costs being $0 \cdot \mathbf{4} 66 d$. per unit. When the extensions at Barking and the new stations at Battersea and Fulham come into operation, even better results will be obtained by the larger stations. The fundamental geographical feature from the point of view of electrical generation is the Thames Valley, with its abundant supply of water for condensation purposes and its facilities for the transport of waterborne coal. In a lecture by J. D. Peattie, published in the Electrician for May 6, an account is given of the interconnexion of the generating stations in the London area. Within a radius of ten miles from Charing Cross, there are now hundreds of lattice towers supporting stranded cables for the grid at 132 kilovolts and for connecting stations at 66 and $33 \mathrm{kv}$. There is a notable river crossing between Barking and Northfleet, where two towers, 487 feet high, will give a clearance under the wires at high water of $250 \mathrm{ft}$. on a span of $3060 \mathrm{ft}$. These towers are the highest on the grid and will carry two double circuits. They are specially painted, and will be illuminated at night to give warning to aircraft flying along the Thames Valley. On the way to Southend one of them is now a conspicuous landmark.

\section{The Hannah Dairy Research Institute}

A BRIEF account of the researches already carried out at the recently established Hannah Dairy Research Institute, Kirkhill, Ayr, is given by the director, Dr. N. C. Wright, in the Ayrshire Cattle Society's Journal, vol. 3, No. 1. An investigation into the incidence of certain bovine diseases, especially tuberculosis and milk fever, has been commenced, and, as a result, recommendations have been made which should lead to the elimination from tested herds of a large proportion of the animals reacting positively to the tuberculin test. Inquiry is also being made into the length of life of milking cows in Scottish herds and into the main causes which lead to the unremunerative disposal of stock. The problems of the utilisation of surplus milk and of milk by-products also received attention. Investigations on the biological side require laboratory accommodation, which has only recently become adequate with the completion of the buildings at Kirkhill. They will include a re-investigation of the protein requirements of dairy cows, and an investigation of the physiology of lactation. In addition, the problems involved in improvement of the dairy stock by selective inbreeding and in the methods used in condensing and drying milk, sepa. rated milk, and whey will be examined. Two-thirds of the income of the Institute is received in the form of a grant from the Development Commissioners, but the remaining third must be raised from non-government sources. It is estimated that $£ 2000$ will be required annually, and it is hoped to secure an endowment fund which will supply an assured income of this order.

No. 3265, VoL. 129]

\section{Anthropological Bibliography}

ANTHROPOLOGY in particular among the sciences is not well served in the matter of indices and bibliographies, though what is needed is, perhaps, co-operation rather than extended effort. There is already in existence a number of bibliographies dealing each with some one or more departments of anthropological science. Some of these overlap, and none can be called really complete. The latest of these has been compiled by M. Joseph Nippgen, librarian of the Société de Géographie of Paris, and has appeared in L'Ethnographie ; it may be obtained separately from the Société d'Ethnographie de Paris. It covers contributions to general and comparative ethnology, and folklore and comparative religion, while ethnographical papers and books dealing with specific geographical areas are grouped under continents. A few items in archæology and physical anthropology are included. This bibliography has the additional advantage that a considerable number of the items are analysed at some length by the compiler. There is, unfortunately, no indication of the period of publication covered by the compilation as a whole, though the latest date appearing is 1929 . The current issue of L'Anthropologie (T. 40, Nos. 5-6) is devoted entirely to an index of vol. 21-40 of that periodical, issued for the years 1910-31. The index is divided into two parts, of which the first contains a list of authors in alphabetical order and the second is a subject index. Titles of original communications and variétés are distinguished from book reviews by a difference in type; but no distinction is made between the names of authors of books reviewed and of original communications. In consequence, the arrangement gives undue prominence to what, from the point of view of most who will wish to consult L'Anthropologie, must be regarded as much in the nature of second-class matter. Notwithstanding this inconvenience, the index is a great boon, and an example that might well be followed with advantage by many more of the British scientific periodicals which have a long run.

\section{New Mayan Site in Yucatan}

A RUINED Mayan city of enormous proportions, previously unknown, has been discovered in southern Yucatan by Mr. C. L. Lundell, a representative of the American Chicle Development Company. The ruins are situated in the south-east corner of Campeche and are difficult of access ; but under an arrangement with the Mexican Government they have been inspected by Dr. Sylvanus G. Morley, accompanied by a party of five. The city has been named Calakmul, "The Two Adjacent Hills", by its discoverer. In Dr. Morley's report, as circulated by Science Service, of Washington, D.C., the site is said to contain many more sculptured monuments than any Mayan city hitherto known. There are no less than one hundred and three stelæ with sculptured figures and hieroglyphs. Some of the stelæ are of high artistic merit. Fifty-one are dated, and one-half of these have been deciphered. It is evident that the city was once a 
great religious centre and a place of outstanding importance in the Old Empire of the Mayas.

\section{Neanderthal Man in Palestine}

A CABLE received by Miss D. A. E. Garrod, director of the joint expedition of the British School of Archæology in Palestine and the American School of Prehistoric Research, announces a further discovery of skeletons in the Mugharet-es-Sukhul cave by Mr. T. McCown. With those previously discovered, the number of individual skeletons now amounts to seven, presumably the relics of a collective burial. The remains are enclosed in a hard breccia in which are also found a large number of stone implements of Mousterian type.

\section{New Atlantic Flight}

Is 1928, Miss Amelia Earhart (Mrs. Putnam) crossed the Atlantic from west to east in an aeroplane with two others, the late Mr. Wilmer Stultz and Mr. Louis Gordon. On Saturday, May 21, she landed near Londonderry, Northern Ireland, having completed a flight from Harbour Grace, Newfoundland, in about fourteen hours. Miss Earhart is thus the first woman flying alone to cross the Atlantic, and she has also set up a new record for the shortest time for the flight. Her machine was a Lockheed Vega monoplane with a Wasp engine of 420 h.p. Four hours out from Harbour Grace, a leaky joint developed in the exhaust of the engine, causing other parts to work loose and set up vibration. There was also danger from petrol leaking into the cockpit from the petrol gauge. For about five hours during the night, Miss Earhart was flying ' blind ' through bad weather, and during this period her altimeter broke down. In spite of these difficulties, Miss Earhart reached the west coast of Ireland and, being uncertain as to her exact bearings, turned north until she saw the country sloping down to the sea. She landed successfully close to Londonderry.

\section{Lewis Evans Collection at Oxford}

THe Committee of Management of the Lewis Evans Collection of Scientific Instruments has issued its Annual Report. Details are given of the important collection of astronomical, optical, magnetic, and mathematical instruments presented by the Royal Astronomical Society of London. This collection is especially valuable as illustrating the period in the history of astronomical measuring which immediately preceded the time when photographic methods began to be employed for the accurate determination of stellar positions. A very notable addition to the collections illustrating the original association of the Old Ashmolean Museum with the study of natural history in Oxford has resulted from the discovery of a part of the great Lhwyd collection of fossils, which had been lost for two centuries, in a cabinet deposited with the Lewis Evans Collection by Oriel College. These fossils, most of which are in their original wrappings inscribed with data, are of the highest historic interest as being part of the first geological collection in Oxford, and especially as being the original type specimens described and in some cases figured by Lhwyd in his classical work on British palæontology.

\section{Barn Owl Census, 1932}

THE diminishing number of barn (or white) owls in England and Wales in recent years is giving concern to agriculturists and students of bird life. In order to obtain information as to the facts of the case, the Royal Society for the Protection of Birds is instituting a census of barn owls breeding during the summer of 1932 ; and helpers are required in every part of the country to find out and record where in their own localities the birds are nesting. All who may be willing and able to assist the inquiry by undertaking to report upon a definite area, are asked to communicate with Mr. G. B. Blaker, Gaveston Place, Nuthurst, nr. Horsham, Sussex, who is organising the work, and to indicate the extent of the area to be allotted to them. Census forms, with suggestions as to how the work may be carried out most easily and effectively, will then be forwarded. It is hoped that valuable information will thus be obtained as to the status of this useful bird.

\section{Prevention of Cherry Fruit Fly}

WiтH the object of preventing the introduction of the cherry fruit fly into England, the Ministry of Agriculture and Fisheries has issued an order (under the Destructive Insects and Pests Acts, 1877 to 1927) which regulates the importation of cherries during the 1932 season. Cherries grown in France will not be admitted after May 27, except those grown within a small district around Honfleur. Cherries grown in Italy will be admitted until June 5, after which date only those grown in the region of Emilia will be allowed to enter; after June 10, the importation of cherries grown in any part of Italy will be entirely prohibited. Cherries grown in Germany will be admitted until June 26 if accompanied by a certificate of origin; after that date, no German cherries will be admitted except those certified not to have been grown south of lat. $53^{\circ} \mathrm{N}$. or in East Prussia.

\section{Important Collections for Harvard Museum}

Two great collections have recently been added, according to Science Service, to the Museum of Comparative Zoology at Harvard. John Eliot Thayer has presented his series of thirty thousand specimens of bird skins, forming probably the finest private collection of North American birds. The collection also contains many thousands of nests and eggs. Some of the specimens are very valuable: extinct birds include the Labrador duck, the Eskimo curlew, and the passenger pigeon. There are ten eggs of the extinct great auk, and several of the California condor, which is becoming very rare. The second collection, bequeathed by Andrew Gray Weeks, contains some 75,000 specimens of butterflies and moths, many being type specimens. The former owner also left to the museum a fund for the care and increase of the collection.

\section{Researches from the London Hospital}

ANOTHER volume of "Researches", published from the wards and laboratories of the London Hospital 